\title{
EFFECTS OF IRRIGATION DEFICIT AND SOWING METHODS ON GROWTH CHARACTRS AND WATER REQUIREMENTS OF SOME WHEAT CULTIVARS \\ El-Seidy, E. H. ${ }^{*}$; A. M. Moussa ${ }^{*}$; U. A. Abd El-Razek ${ }^{*}$ and M. O. Al-Farouk \\ Department of Agronomy, Fac. of Agric., Tanta University. \\ ** Wheat Research Dept., Field Crops Research Inst., ARC.
}

\begin{abstract}
In order to investigate the influence of different irrigation regimes i.e. irrigation at tillering stage $\left(I_{1}\right)$, at tillering and heading stage $\left(I_{2}\right)$ at tillering, heading and grain filling stage $\left(I_{3}\right)$ of the available soil moisture depletion with three methods of sowing i.e. broadcasting, drilling and beds sowing on some and characters of growth attributes, relative water content, water use efficiency and drought susceptibility index for four wheat cultivars namely; Gemmeiza-11,Misr-1, Shandaweel-1 and Sids-12. So, two field trials was carried out during 2011/12 and 2012/13 seasons, at El- Gemmeiza Agric. Res. Stat. The results can be summarized as follows:

Subjecting wheat plants to drought-stress resulted in a significant reduction in plant height, number of days to heading, number of days to maturity, grain filling period, flag leaf area and relative water content. Water use efficiency and total chlorophyll content tends significantly increased as irrigation regime decreased. Moreover, number of days to heading, number of days to maturity, grain filling period and flag leaf area were insignificant differed due to the tested sowing methods. However, beds sowing method was significantly differed total chlorophyll content, relative water content and water use efficiency. Gemmeiza-11 cultivar surpassed others tested cultivars with respect the abovementioned traits, except number of days to maturity since Shandaweel-1 cultivar was the earliest. Wheat plants grown under severe water deficit were more sensitive to drought. This was clear from drought sensitivity based on drought susceptibility index. Sids-12 and Misr-1 cultivars was proved to be the most drought-tolerant cultivar compared to the other tested ones.

Keywords: Wheat, irrigation regimes, water requirements, sowing methods, drought susceptibility index.
\end{abstract}

\section{INTRODUCTION}

Wheat (Triticum aestivum, L.) has been considered the first strategic food crop for more than 7000 years in Egypt. It has maintained its position during that time as the basic staple food in urban areas and mixed with maize in rural areas for bread making. In addition, it straw is an important as fodder for animals (Gomaa,1999).

The annual consumption of wheat grains in Egypt is about 15 million tons, while the annual local production is about 9 million tons in 2014. Egypt strategy is to minimize the food gap of this crop particular throughout vertical (increment of productivity per unit area) improvement and horizontal (increase of cultivated area) expansion. Area productivity could be improved through usage of high yielding varieties and optimum cultural practices through better crop management.

In Egypt, the water and agricultural land resources are limited, so it is must to use such resources efficiently in order to accomplish the sustainable 
agriculture concept. In the context of improving water productivity, there is a growing interest in deficit irrigation, which is an irrigation practice where by water supply is reduced below maximum levels and mild stress is allowed with minimal effects on yield.

Irrigation could be considered the limiting factor affecting crop production and agricultural expansion. in Egypt, especially in Nile Valley and Delta region, where farmers use extra water to irrigate their farms. So, irrigation optimization, i.e. applying the irrigation water timely and quantitatively will increase wheat yield and save considerable amount of water. Many researchers proved the importance of irrigation treatment to maximize wheat productivity. In this respect, Hefnawy and Wahba (2003) reported that there were no significant differences in wheat grain yield between five and six irrigation treatments. One irrigation for wheat is equal to about $400 \mathrm{~m}^{3} / \mathrm{fad}$. The saved amount of water can be used in the agricultural projects in newly reclaimed areas.

Optimum sowing method of wheat has a beneficial role in affecting wheat plant distribution in the field as well as water and nutrients use efficiencies for grown plants and subsequent optimum yields. Sowing method in wheat, like other crops, responds greatly to various agro-management practices, and it affected to yield and its characters. Concerning sowing pattern, there are some benefits sowing on beds such as low seed rate, decreasing of field traffic, better irrigation management facilities, reducing crop lodging and herbicide dependence, the control of root diseases and better usage of chemical application machines.(Sayre and Ramos, 1997) observed that sowing of wheat on beds increased grain yield of wheat up to $21 \%$ over conventional method of drill sowing. Soomro et al. (2009) reported that plant height, flag leaf area and grain filling period were higher in drill planted wheat than broadcasted.

Therefore, the objectives of this research was aimed to evaluate the effect of irrigation regimes and sowing methods as well as their interaction on growth characteristics and water requirements of four Egyptian bread wheat cultivars.

\section{MATERIALS AND METHODS}

The present investigation was carried out at El-Gemmeiza Agric. Res. Stat., A.R.C., El- Gharbeia Governorate, Egypt. During the two growing successive seasons of 2011/12 and 2012/13 to study the effect of three irrigation regimes and three sowing methods on growth attributes and water requirements of four bread wheat cultivars (Triticum aestivum L.). These cultivars selection were based on the productivity and diseases resistant collected from different sources.

The experimental design was a split-split- plot design with four replications was used in both seasons. The main plot treatments were occupied by the three irrigation regimes, while the three sowing methods were assigned in the sub- plots and the four wheat cultivars in the sub- subplots. Seeds were sown on $20^{\text {th }}$ November in the first season and on $25^{\text {th }}$ November in the second growing season. The harvest area was $8.4 \mathrm{~m}^{2}$ i.e. 
2.4 width and $3.5 \mathrm{~m}$ in length. The amount of nitrogen was divided into two portions; one being applied immediately before the first irrigation and the rest was applied before the second irrigation. Nitrogen was added in the form of urea $(46 \% \mathrm{~N})$.Phosphate fertilizer was applied at the rate of $100 \mathrm{~kg}$ calcium superphosphate/fad. (15.5 kg $\left.\mathrm{P}_{2} \mathrm{O}_{5}\right)$ during seedbed preparation .The preceding crop was cotton in both seasons. The mechanical and chemical properties of the experimental field soil are shown in Table (2).A brief information concerning the microclimatic data during the two growing seasons are given in Table (3). Experimental factors included the following:

\section{A. Irrigation regimes (I):}

$\mathrm{I}_{1}=$ One irrigations i.e. at tillering stage, $\mathrm{I}_{2}=$ Two irrigations i.e. at tillering and heading stage and $I_{3}=$ Three irrigations i.e. at tillering, heading and grain filling stage and accumulation water applied were applied as shown in Table (1). Irrigation water was delivered to the plots through a circular orifice and water quantity was measured using the formula of immersed orifice according to (James, 1988) as follows:

$$
Q=0.61 \times 0.443 \times A \sqrt{h}
$$

Where:

$$
\mathrm{Q}=\text { Orifice discharge, } \mathrm{L} / \mathrm{sec} . \quad \mathrm{A}=\text { Area of orifice, } \mathrm{cm}^{2} \text {. }
$$

$\mathrm{h}=$ Effective water head over the orifice center $(\mathrm{m})$.

$B$. Sowing methods (M):

$M_{1}=$ Broadcasting method, $M_{2}=$ Drilling method and $M_{3}=$ Beds method.

C.Wheat cultivars (V):

$\mathrm{V}_{1}=$ Gemmeiza $-11, \mathrm{~V}_{2}=$ Misr $-1, \mathrm{~V}_{3}=$ Shandaweel -1 and $\mathrm{V}_{4}=$ Sids -12

The studied characters:

A-Vegetative characteristics: Plant height, Days to heading, Days to maturity, Grain filling period, Flag leaf area and Total chlorophyll content.

B- Drought characters:

1- Leaf relative water content (RWC\%): was determined according to Barrs and weatherley (1962) equation:

$R W C=(F w-D w) /(T w-D w) \times 100$

where $\mathrm{Fw}$ is the fresh weight of the leaf sample, Dw is dry weight of leaf sample, Tw is the weight of fresh leaf floated in distilled water for $8 \mathrm{hrs}$.

2- Water use efficiency (WUE): Water productivity is an efficiency term calculated as a ratio of product output (goods and services) over water input.

WUE $=$ Grain yield $(\mathrm{kg} / \mathrm{fad}) /$ Irrigation water supplied $(\mathrm{mm} / \mathrm{fad})$.

C- Drought susceptibility index for grain yield, DSI: The index (DSI) was calculated from genotype means for grain yield using a generalized formula (Fisher and Maurer 1978) in which: SI = (1 - yd/ yp) / D.

Statistical analysis:

All the data collected were subjected to statistical analysis of variance as described by Sendecor and Chochran (1981) and treatment means were compared by least significant difference (LSD) at $5 \%$ and $1 \%$ level of probability. 
Table 1: Date and quantity of irrigation water and accumulated water applied $(\mathrm{mm})$ under different irrigation regimes in 2011/12 and 2012/13 seasons.

\begin{tabular}{|c|c|c|c|c|c|c|c|}
\hline $\begin{array}{l}\text { Preceding } \\
\text { crop }\end{array}$ & \begin{tabular}{|c|} 
Irrigation \\
regimes
\end{tabular} & $\begin{array}{c}\text { Sowing } \\
\text { date }\end{array}$ & $\begin{array}{l}\text { Mohayah } \\
\text { irrigation }\end{array}$ & $\begin{array}{c}1^{\text {st }} \\
\text { irrigation }\end{array}$ & $\begin{array}{c}2^{\text {nd }} \\
\text { irrigation }\end{array}$ & $\begin{array}{c}3^{\text {rd }} \\
\text { irrigation }\end{array}$ & $\begin{array}{l}\text { Accumulation } \\
\text { water applied }\end{array}$ \\
\hline \multicolumn{8}{|c|}{$2011 / 12$ season } \\
\hline \multirow{6}{*}{ Cotton } & $I_{1}$ Date & $20 / 11 / 2011$ & $11 / 12 / 2011$ & $16 / 2 / 2012$ & - & - & \\
\hline & $\mathrm{Q}(\mathrm{mm})$ & 156.8 & 92.3 & 233.0 & - & - & 482.1 \\
\hline & $\mathrm{I}_{2}$ Date & $20 / 11 / 2011$ & $11 / 12 / 2011$ & 9/2/2012 & 10/3/2012 & - & \\
\hline & $\mathrm{Q}(\mathrm{mm})$ & 156.8 & 92.3 & 168.3 & 135.4 & - & 552.8 \\
\hline & $I_{3}$ Date & $20 / 11 / 2011$ & $11 / 12 / 2011$ & $25 / 1 / 2012$ & $3 / 3 / 2012$ & $2 / 4 / 2012$ & \\
\hline & $\mathrm{Q}(\mathrm{mm})$ & 156.8 & 92.3 & 111.2 & 123.8 & 106.0 & 590.1 \\
\hline \multicolumn{8}{|c|}{ 2012/13 season } \\
\hline \multirow{6}{*}{ Cotton } & $l_{1}$ Date & $25 / 11 / 2012$ & $17 / 12 / 2012$ & $19 / 3 / 2013$ & - & - & \\
\hline & $\mathrm{Q}(\mathrm{mm})$ & 106.6 & 103.3 & 224.4 & - & - & 434.3 \\
\hline & $I_{2}$ Date & $25 / 11 / 2012$ & $17 / 12 / 2012$ & $17 / 2 / 2013$ & $1 / 4 / 2013$ & - & \\
\hline & $\mathrm{Q}(\mathrm{mm})$ & 106.6 & 103.3 & 120.4 & 115.0 & - & 445.3 \\
\hline & $I_{3}$ Date & $25 / 11 / 2012$ & $17 / 12 / 2012$ & $27 / 1 / 2013$ & $29 / 2 / 2013$ & $2 / 4 / 2013$ & \\
\hline & $\mathrm{Q}(\mathrm{mm})$ & 106.6 & 103.3 & 91.3 & 118.1 & 99.3 & 518.6 \\
\hline
\end{tabular}

Table 2: Mechanical and chemical analysis of experimental sites during 2011/12 and 2012/13 wheat seasons.

\begin{tabular}{|l|c|c|}
\hline \multirow{2}{*}{ Variable } & \multicolumn{2}{|c|}{ Seasons } \\
\cline { 2 - 3 } & Mechanical analysis \\
\hline Coarse sand (\%) & 1.1 & $\mathbf{2 0 1 2 / 1 3}$ \\
\hline Fine sand (\%) & 16.30 & 1.2 \\
\hline Silt (\%) & 31.50 & 15.62 \\
\hline Clay (\%) & 51.10 & 33.66 \\
\hline Soil texture class & Clay & 49.52 \\
\hline \multicolumn{2}{|c|}{ Chemical analysis } \\
\hline Available N ppm & 43.67 & Clay \\
\hline Available P ppm & 3.27 & 55.00 \\
\hline Available K ppm & 225 & 4.35 \\
\hline Organic matter \% & 0.75 & 240 \\
\hline PH $^{*}$ & 8.12 & 0.77 \\
\hline EC $^{* *}$ & 1.34 & 8.18 \\
\hline
\end{tabular}

$\mathrm{PH}^{\prime}$ was determined in saturated soil paste.

$\mathrm{EC}^{* *}$ and soluble ions were determined in soil water paste extract.

Table 3: Monthly mean air temperature $\left(C^{\circ}\right)$, mean relative humidity (RH $\%$ ) and rainfall $(\mathrm{mm} / \mathrm{day})$ in winter season of $2011 / 12$ and 2012/13 at El - Gemmeiza site.

\begin{tabular}{|l|c|c|c|c|c|c|c|c|c|c|}
\hline \multirow{3}{*}{ Month } & \multicolumn{3}{|c|}{ Temperature $\left(\mathbf{C}^{\mathbf{0}}\right)$} & \multicolumn{4}{c|}{ (RH \%) } & \multicolumn{2}{c|}{ Rainfall (mm) } \\
\cline { 2 - 11 } & Max. & Min. & Max. & Min. & Max. & Min. & Max. & Min. & Mean & Mean \\
\cline { 2 - 10 } & $2011 / 12$ & $2012 / 13$ & \multicolumn{2}{|c|}{$2011 / 12$} & $2012 / 13$ & $2011 / 12$ & $2012 / 13$ \\
\hline Nov. & 29.4 & 14.7 & 30.2 & 16.0 & 63.0 & 36.0 & 64.0 & 43.0 & 0.140 & 0.000 \\
\hline Dec. & 19.4 & 14.0 & 20.9 & 14.6 & 76.3 & 43.8 & 79.4 & 44.2 & 0.150 & 0.560 \\
\hline Jan. & 17.8 & 14.5 & 18.6 & 15.1 & 80.5 & 46.5 & 80.1 & 54.5 & 0.185 & 0.255 \\
\hline Feb. & 22.1 & 13.9 & 23.7 & 16.2 & 77.8 & 51.1 & 82.5 & 55.6 & 0.530 & 0.190 \\
\hline Mar. & 23.6 & 13.7 & 25.5 & 14.7 & 75.6 & 45.1 & 80.0 & 51.3 & 0.210 & 0.225 \\
\hline Apr. & 29.0 & 15.5 & 30.1 & 17.0 & 68.6 & 41.1 & 73.4 & 49.5 & 0.000 & 0.000 \\
\hline
\end{tabular}

Max = maximum, Min = minimum. 


\section{RESULTS AND DISCUSSION}

\section{A- Vegetative characteristics:}

\section{Effect of irrigation treatments (I).}

Results in Table (4) showed that irrigation treatments had a significant effect on plant height, days to heading, days to maturity, flag leaf area and total chlorophyll content in both seasons. However, grain filling period, did not affected by irrigation treatments in the second season only.

The tallest wheat plants $(113.50$ and $115.77 \mathrm{~cm})$ in the two seasons, respectively, were recorded by using three irrigation regimes $\left(I_{3}\right)$. One irrigated at sowing $\left(\mathrm{l}_{1}\right)$ produced the shortest plants $(110.71$ and $113.12 \mathrm{~cm})$ at the first and second seasons, respectively. It was clear from the obtained data that increasing irrigation treatments significantly increased plant height due to available both moisture and nutrients help the plant to produce more growth and elongation the internode of the stem. The results are in harmony with those recorded by Moghaddam et al. (2012), and Genedy (2014). Mean values indicated that the earliest wheat plants for days to heading were obtained as a result of water stress only one irrigation $\left(I_{1}\right)$ which recorded the lowest numbers of days to heading (103.65 and 101.04 days) in both growing seasons, respectively. In general, applied more irrigations caused an increase in number of days to heading up to (106.21 and 104.38 days) when applied three irrigations $\left(\mathrm{I}_{3}\right)$. Normal irrigation encouraged more available of moisture and nutrient caused the initiation of more tillers, elongated the vegetative growth period, and hence delayed heading days. Many researchers have indicated wheat plant under unfavorable conditions such as drought, salinity and heat finished its life cycle as a kind of escape from these conditions. These results are in agreement with those obtained by Moghaddam et al.(2012) and El- Hag (2015). Increasing number of irrigation significantly increased number of days to maturity in both growing seasons. Three irrigations $\left(I_{3}\right)$ recorded (156.13 and 153.73days) as compared with (154.52 and 150.63 days) when wheat cultivars were watering with one irrigation $\left(\mathrm{I}_{1}\right)$ in both seasons, respectively. These results are in agreement with those obtained by Moghaddam et al. (2012), and Genedy (2014).

Analysis of variance for grain filling period indicated that variations due to irrigation treatments were significant at the first season only Table (4). One irrigation number $\left(I_{1}\right)$ decreased grain filling period and recorded the lowest number of days for grain filling period (49.91 days) in the first season, comparing with three irrigations $\left(\mathrm{I}_{3}\right)$, which recorded the highest number of days (51.73 days) in the first season. These results agreed with those obtained by Sharshar (2010) and El-Hag (2015) Regarding the effect of irrigation treatment on flag leaf area, the results indicated that there were highly significant effects in both seasons, Table(4). Generally, increasing number of irrigations treatment increased significantly the value of flag leaf area were recorded $\left(47.05\right.$ and $\left.49.17 \mathrm{~cm}^{2}\right)$ in both seasons, respectively. The increase in number of irrigations increased available nutrients increased the division cells and caused to increase both the growth and the area of leaves. 
The results are in harmony with those obtained by El-Shamy (2009) and Sharshar (2010).

Analysis of variance of total chlorophyll content indicated that variations due to irrigation treatments were significant effect in two seasons, Table (4). Mean values indicated that wheat plants, which received one irrigation $\left(I_{1}\right)$ expressed a significant increase in this character compared to those received three irrigations $\left(\mathrm{I}_{3}\right)$ in both seasons. Water stress during grain filling stages, induced early senescence, reduced photosynthesis, increased the remobilization of carbohydrates from vegetative tissues to the grain and shortened grain filling period. These results agree with those obtained by Sharshar (2010).

\section{Sowing methods effects (M).}

Results revealed that sowing methods had a significant effect on plant height at harvest time in both seasons Table (4). The beds sowing gave the tallest plants $(113.40$ and $115.59 \mathrm{~cm}$.) in both seasons, respectively. These results could be due to the bed method had led to the optimum conditions of good standing, better field air circulation and higher nitrogenfertilizer use efficiency (NUE) relative to the other two methods. These results are in harmony with those obtained by Sharshar (2010) and Genedy (2014). Sowing method caused an insignificant effect in number of days to heading in both seasons, Table (4). The results agreed with that obtained by Genedy (2014). Data in Table (4), also indicated that sowing method had insignificant effects on number of days to maturity. Analogous resulted were obtained by Soomro et al. (2009) and Genedy (2014). With regard to the effect of sowing method on grain filling period, data in Table (4), show a insignificant effect in the two seasons. These results are in agreement with El-Hag (2015). Data presented in Table(4), showed that flag leaf area had significantly affected by sowing method in both seasons. Beds sowing method recorded the highest value of flag leaf area $(45.38$ and $47.65 \mathrm{~cm})$ in both seasons, respectively, relative to the other two methods. This may be due to the beds method had given the optimum conditions and nitrogen-fertilizer use efficiency (NUE) of comparable relative to the other methods. Results are in agreement with those obtained by Ali et al. (2012). With regard to the effect of sowing method on chlorophyll content as shown in Table (4), the effects were significant in both seasons. Bed sowing method in the first season recorded the highest chlorophyll content (46.38), while, drill method in the second season gave the highest value of this trait (48.82), which the broadcast method of planting gave the lowest one in both seasons. The obtained results could be to the excellent plant distribution in the field. Moreover, raised bed planting produced a more ideal plant structure composed of larger basal leaves with smaller top leaves. These results are in harmony with Radwan et al.(2013).

\section{Wheat cultivars performance (V).}

Results in Table (4) indicated that there significant differences among wheat cultivars for plant height in both seasons. Gemmeiza-11, followed by Sids-12 gave the tallest plants $(114.68,113.27,117.91$ and $115.98 \mathrm{~cm}$.) in both seasons, respectively. Differences in plant height among the tested genotypes may be due to their different genetic background as well as their interaction with the environmental factors. These results are in a good 
accordance with those obtained by Sharshar (2010) and El- Hag (2012). The results revealed that, there were significant differences among wheat cultivars in number of days to heading in both seasons, Table (4). Gemmeiza-11 was the earliest one (103.47 and 100.58 days) in both seasons, respectively. Meanwhile, Shandaweel-1 recorded the latest number of days to heading (106.75and 105.5 days) in both seasons, respectively. Difference in heading dates among wheat genotypes may be due to the genetic constitution, which seriously affected by environmental conditions. These results are in agreement with those obtained by Ngwako and Mashiqa (2013). Among wheat cultivars the differences were significant in maturity date in both seasons, Table (4). Shandaweel-1 was the earliest wheat cultivars, which recorded (154.75 and 150.33 days) at the first and second season, respectively. Sids-12 and Misr-1 were the latest cultivars in maturity date which recorded (155.50, 157.19, 154.42 and 152.75 days) in both seasons, respectively. Similar conclusion were reported by Moayedi et al. (2010) and El- Hag (2012). Differences among wheat cultivars were highly significant on grain filling period in both seasons, Table (4). Shandaweel-1 recorded the shortest grain filling period (48.00 and 44.83 days) in both seasons, respectively. Meanwhile, the longest grain filling periods (53.06 and 52.39 days) recorded by Sids-12 and Gemmeiza- 11 at the first season, while Misr-1 and Gemmeiza-11 gave (52.89 and 52.17 days) in the second season. These results are in a harmony with those obtained by Sharshar (2010), ElHag (2012). Data presented in Table (4), indicates that flag leaf area significantly affected by cultivars in both seasons. Gemmeiza-11 recorded the highest values of flag leaf area in both seasons (52.68 and $52.54 \mathrm{~cm}^{2}$ ), respectively. On the other hand, Shandaweel-1 and Misr-1 were recorded the lowest values of flag leaf area $\left(37.91\right.$ and $\left.41.19 \mathrm{~cm}^{2}\right)$ in the first and second seasons, respectively. These results are in harmony with those reported by El- Hag (2012) and El- Hag (2015). Grown cultivars showed differences in leaf chlorophyll content Table (4), in both seasons. Gemmeiza-11 had the highest chlorophyll content followed significant differences by Sids- 12 . Whereas, Misr-1 and Shandaweel-1 leaves had the lowest chlorophyll content. The obtained results are in accordance with those of Abu-Grab et al. (2006) and Ngwako and Mashiqa (2013) who found that significant variations in some wheat respect to their leaf chlorophyll content. These differences might be attributed to the genetic diversity between cultivars.

\section{Interaction Effect.}

The interactions between all treatments of study (first and second orderd) were not significant for plant height, days to heading, days to maturity, grain filling period, Flag leaf area and total chlorophyll content in both seasons, Table (4).

\section{B- Drought characters:}

\section{Effect of irrigation treatments (I).}

Means of relative water content as affected by irrigation treatment, sowing method, wheat cultivars and their interactions are shown in Table(5), in both seasons. Relative water content is defined as the water lost from the plants organs, specially leaves surface, and namely transpiration besides that 
evaporated from the soil surface during the entire growing season. Data in Table (5) revealed that, relative water content values were significantly increased as irrigation regime increased. The increase in relative water content values under $\left(I_{3}\right),(81.51$ and 80.96$)$ were more than those under $\left(I_{1}\right)$, (75.17 and 75.93) and ( $\left.\mathrm{I}_{2}\right),(79.30$ and 78.88) in both seasons, respectively. These results were attributed to more available soil moisture, under $\left(I_{3}\right)$ treatment, which inhanced both transpiration from plants leaves and evaporation from the soil surface. Similar results were reported by Hefnawy and Wahba (2003). Means of water use efficiency (WUE) as affected by irrigation treatments, sowing method, wheat cultivars and their interactions are show in Table (5) in both seasons. Water use efficiency (WUE) means kg of grains produced due to consumption $1 \mathrm{~mm}$ water depth of soil moisture per faddan. Data in Table (5) indicate that, (WUE) values were significantly differed under the adopted irrigation regimes, and the value was increased as irrigation moisture regime decreased. The increase in (WUE) value under $\left(I_{1}\right)$ were more than those under $\left(I_{2}\right)$ and $\left(I_{3}\right)$ by $21.49 \%$ and $54.26 \%$ in the first season, while the corresponding increase in the second season were $22.28 \%$ and $66.13 \%$. Other researchers indicate (WUE) values were increased with irrigation after higher soil moisture depletion, Hefnawy and Wahba (2003).These results agreement with those reported by Genedy (2014).

\section{Sowing methods effects (M).}

Results in Table (5) revealed that, relative water content significantly affected by sowing methods, beds method recorded (80.97 and $80.25 \%$ ), while drill and broadcat methods recorded $(76.36,78.65,78.73$ and $76.80 \%)$ in the first and the second seasons, respectively. The beds method had realized to the optimum conditions. It recorded the highest values of relative water content due to lowering amount of water requirements, which that allowed relative to the other methods. These results are in agreed with those revealed by Genedy (2014). As indicated in the same Table (5) WUE parameter significantly affected by sowing methods, the highest values was obtained by beds method treatment $(8.73$ and $7.99 \mathrm{~mm} / \mathrm{fad})$, while drill sowing method recorded $(8.12$ and $6.94 \mathrm{~mm} / \mathrm{fad})$ and broadcaste method gave $(7.75$ and $7.38 \mathrm{~mm} / \mathrm{fad}$ ) in both seasons, respectively. The beds method had realized to the optimum conditions. It recorded the highest values of WUE due to lowering amount of water requirements, which that allowed relative to the two methods. The results in accordance with those obtained by Genedy (2014) and El-Hag (2015). 
J. Plant Production, Mansoura Univ., Vol. 6 (5), May, 2015

Table (4) 
Table 5: Effects of irrigation numbers, sowing methods, cultivars and their interactions on relative water content (\%) and water use efficiency $(\mathrm{mm} / \mathrm{fad})$ in two seasons 2011/12 and $2012 / 13$.

\begin{tabular}{|c|c|c|c|c|}
\hline \multirow{2}{*}{\begin{tabular}{|l|}
\multicolumn{2}{|c}{ Characters } \\
Treatments
\end{tabular}} & \multicolumn{2}{|c|}{ Relative water content (\%) } & \multicolumn{2}{|c|}{$\begin{array}{c}\text { Water use efficiency } \\
(\mathrm{mm} / \mathrm{fad})\end{array}$} \\
\hline & $2011 / 12$ & $2012 / 13$ & 2011/12 & 2012/13 \\
\hline \multicolumn{5}{|c|}{ A: Irrigation (I) } \\
\hline $\mathrm{l}_{1}$ (One) & 75.17 & 75.93 & 9.95 & 9.22 \\
\hline $\mathrm{I}_{2}$ (Two) & 79.30 & 78.88 & 8.19 & 7.54 \\
\hline $\mathrm{I}_{3}$ (Three) & 81.51 & 80.96 & 6.45 & 5.55 \\
\hline F- test & ** & $\star \star \star$ & ** & $\star \star \star *$ \\
\hline LSD 0.05 & - & - & - & - \\
\hline 0.01 & 0.78 & 0.41 & 1.04 & 0.93 \\
\hline \multicolumn{5}{|c|}{ B: Sowing methods (M) } \\
\hline Broadcasting & 76.36 & 78.73 & 7.75 & 7.38 \\
\hline Drilling & 78.65 & 76.80 & 8.12 & 6.94 \\
\hline Beds & 80.97 & 80.25 & 8.73 & 7.99 \\
\hline F- test & ** & ** & ** & ** \\
\hline LSD 0.05 & - & - & - & - \\
\hline 0.01 & 1.07 & 1.07 & 0.63 & 0.72 \\
\hline \multicolumn{5}{|c|}{ C: Cultivars (V) } \\
\hline Gemmeiza 11 & 81.50 & 81.19 & 9.48 & 8.73 \\
\hline Misr 1 & 79.55 & 78.11 & 8.66 & 7.09 \\
\hline Shandaweel 1 & 77.70 & 75.48 & 6.79 & 6.20 \\
\hline Sids 12 & 75.89 & 79.58 & 7.86 & 7.73 \\
\hline F- test & ** & ** & ** & ** \\
\hline LSD 0.05 & - & - & - & - \\
\hline 0.01 & 1.14 & 1.11 & 0.63 & 0.63 \\
\hline \multicolumn{5}{|c|}{ D: Interactions effects } \\
\hline$I \times M$ & NS & NS & NS & NS \\
\hline $\mathrm{I} \times \mathrm{V}$ & NS & NS & NS & * \\
\hline $\mathrm{M} \times \mathrm{V}$ & NS & NS & NS & NS \\
\hline $\mathrm{I} \times \mathrm{M} \times \mathrm{V}$ & NS & NS & NS & NS \\
\hline
\end{tabular}

3. Wheat cultivars performance (V).

The obtained data showed that the tested wheat cultivars were significantly differed with respect to relative water content values and the higher value was noticed with Gemmeiza-11 cultivar, as compared with the other tested cultivars in the two seasons.

Regarding to the effect of wheat cultivars on WUE, data presented in Table (5) revealed that WUE was highly significant affected by wheat cultivars in both seasons. Gemmeiza-11 and Misr-1 in the first season and Gemmeiza-11 and Sids-12 in the second season produced maximum WUE (9.48 and $8.66 \mathrm{~mm} / \mathrm{fad})$ and $(8.73$ and $7.73 \mathrm{~mm} / \mathrm{fad})$. These results are in agreement with El-Hag (2015). 
Table 6: Effect of irrigation numbers $\mathrm{x}$ cultivars interactions on water use efficiency (mm/fad) in one season 2012/13.

\begin{tabular}{|l|c|c|c|}
\hline \multirow{2}{*}{ Cultivars (V) } & \multicolumn{3}{|c|}{ Irrigation numbers (I) } \\
\cline { 2 - 4 } & $\mathrm{I}_{1}$ (One) & $\mathrm{I}_{2}($ Two $)$ & $\mathrm{I}_{3}($ Three $)$ \\
\hline Gemmeiza 11 & 10.07 & 8.65 & 7.45 \\
\hline Misr 1 & 9.03 & 7.30 & 4.96 \\
\hline Shandaweel 1 & 8.35 & 6.45 & 3.78 \\
\hline Sids 12 & 9.44 & 7.75 & 6.01 \\
\hline LSD 0.05 & \multicolumn{3}{|c|}{1.00} \\
\cline { 2 - 4 } 0.01 & \multicolumn{3}{|c|}{1.52} \\
\hline
\end{tabular}

\section{Interaction Effect.}

Results cleared that relative water content values and water use efficiency were insignificantly influenced in both seasons as interactions of irrigation regimes, sowing methods and wheat cultivars in the first and second orders, except (I XV) in the second season for WUE Table (5). Gemmeiza-11 wheat cultivar under one irrigation $\left(I_{1}\right)$ recorded the highest WUE (10.07 $\mathrm{mm} / \mathrm{fad}$.) in the second season. The other interactions did not reach the level of significant Table (6).

\section{C- Drought susceptibility index for grain yield (DSI).}

The susceptibility index was used to estimate relative susceptibility to stress injury because it accounted for variation in yield potentials and environmental stress intensity, as presented in Table (7). Low stress susceptibility $(S<1)$ is synonymous with higher stress tolerance, while high susceptibility index $(\mathrm{SI}>1)$ mean higher stress sensitivity (Fisher and Maurer ,1978). Application of Yield based on $\mathrm{Sl}_{1}$ over two and three irrigation treatments. Drought susceptibility index was used as a parameter to provide a measure of stress resistance based on minimization of yield loss under stress as compared to the optimum condition rather than on yield level under non-stress. The results in Table (7) showed that, when wheat sown under broadcaste, drill and beds methods of sowing Misr-1 and Sids-12 were belong to the first group $(S<1)$, while the other two genotypes were belong to the second group $(\mathrm{SI}>1)$ in the first and second seasons, respectively. These results indicated that these genotypes are more tolerant under stress conditions and could be involved in breeding programs to develop wheat genotypes suitable for growing under stress conditions. These results are in agreement with those obtained by Akbari et al. (2011) and El-Hag (2015).

Generally, it could be concluded that irrigation (at tillering, heading and grain filling stage) and sown Gemmeiza-11 cultivar. The beds planting method should be applied in the condition of irrigation water deficit. 
Table 7: Drought susceptibility index (DSI) of grain yield for the studied four wheat cultivars in 2011/12 and 2012/13 growing seasons.

\begin{tabular}{|l|c|c|c|c|c|c|}
\hline \multirow{2}{*}{$\begin{array}{l}\text { Wheat } \\
\text { cultivars }\end{array}$} & \multicolumn{3}{|c|}{$\mathbf{2 0 1 1 / 1 2}$} & \multicolumn{3}{c|}{$\mathbf{2 0 1 2 / 1 3}$} \\
\cline { 2 - 7 } & Broadcasting & Drilling & Beds & Broadcasting & Drilling & Beds \\
\hline Gemmeiza11 & 1.83 & 1.31 & 1.04 & 1.07 & 1.56 & 1.51 \\
\hline Misr1 & 0.32 & 0.12 & 0.50 & 0.61 & 0.59 & 0.64 \\
\hline Shandaweel 1 & 1.48 & 1.59 & 1.61 & 1.34 & 0.89 & 0.93 \\
\hline Sids12 & 0.25 & 0.98 & 0.86 & 0.98 & 0.85 & 0.80 \\
\hline
\end{tabular}

\section{REFERENCES}

Abu-Grab, O.S.; A.M. Moussa and G.A. El-Shaarawy (2006). Photosynthetic and $\mathrm{N}$-use efficiencies for some wheat cultivars in relation to planting density and nitrogen fertilization level. Egypt. J. Appl. Sci., 21(2): 475492.

Akbari M. H.; M. Galavi; H.R. Fanaei; SH.A. Koohkan and O. Poodineh (2011). Effects of deficit irrigation on grain yield and some morphological traits of wheat cultivars in drought - prone conditions. International Journal of Agricultural Sciences , 1(4): 249-257.

Ali, M.; L. Ali; M.Q. Waqar and M.A. Ali (2012). Bed planting: A new crop establishment method for wheat (Triticum aestivum L.) in cotton-wheat cropping system of Southern Punjab. Int. J. Agric. Appl. Sci., 4(1): 8-14.

Barrs, H.D. and P.F.Weatherley (1962). A reexamination of relative turgidity technique of estimating water deficit in leaves. Aust.J.Biol.Sci.,15:413428.

El- Hag, Dalia, A. A. (2012). Effect of planting date and nitrogen level on yield and quality of bread and durum wheat. Ph D. Thesis, Kafrelsheikh Univ., Egypt.

El-Hag, Walaa, A.A. (2015). Morphological studies on bread wheat under different regimes and planting methods. Ph D.Thesis, Fac. of Agric. Kaferelshikh Univ., Egypt.

El-Shamy, A. E. A. (2009). Evaluation of some wheat hybrids for drought tolerance. M.Sc. Thesis, Kafrelsheikh Univ., Egypt.

Fisher, R.A. and R. Maurer (1978). Drought resistance in spring wheat cultivars. I. Grain yield responses. Asut. J. Agric. Res., 29: 897-912.

Genedy, M. S. A. (2014). Effect of some planting methods, nitrogen fertilization rates and irrigation on wheat grain yield. $\mathrm{Ph} \mathrm{D}$. Thesis, Mansoura Univ., Egypt.

Gommaa, A.S.A (1999). Wheat improvement in Egypt: History and future prospects. Egypt. J. Plant Breeding, 3: 1-14.

Hefnawy F.A and M.F. Wahba (2003). Effect of water stress in late growth stages of some wheat cultivars. J. Agric. Sci., Mansoura Univ., 28 (2):729-745.

James, L.G. (1988). Principles of Farm Irrigation System Design. PP.106128. John Wiley\& Sons, New York. 
Moayedi, A. A.; A. N. Boyce and S. S. Barakbah (2010). The performance of durum and bread wheat genotypes associated with yield and yield component under different water deficit conditions. Australian Journal of Basic and Applied Sciences, 4(1): 106-113.

Moghaddam H.A.; M. Galavi; M. Soluki; B. Siahsar; S.M.M. Nik and M. Heidari (2012). Effects of deficit irrigation on yield, yield components and some morphological traits of wheat cultivars under field conditions. Int. J. Agric. Res. and Rev., 2: 825-833.

Ngwako S. and P. K. Mashiqa (2013). The effect of irrigation on the growth and yield of winter wheat (Triticum aestivum L.) cultivars. Int. J. Agri., Crop Sci., 5 (9):976-982.

Radwan, F.I.; M.A. Gomaa; M.A. Nasser; E.E. Kandil and S.F. lamlom (2013).Effect of sowing methods and bio-organic fertilization on growth, yield and yield components of wheat (Triticum aestivum L.) Research Journal of Agriculture and Biological Sciences, 9(1): 70-78.

Sayre, K.D. and O.H. Ramos (1997). Applications of raised- bed planting systems to wheat.Wheat Program Special Report No.31. Mexico, DF: CIMMYT.

Sharshar, A.M. (2010). Combining ability and heterosis for bread wheat under stress and normal irrigation treatments. M. Sc. Thesis, Fac. of Agric. Kafrelsheikh Univ.

Snedecor, G.W. and W.G. Chochran (1981). "Statistical Methods" $6^{\text {th }}$ Edn., lowa State Univ. Press, lowa, USA.

Soomro, U.A.; M.U. Rahman; E.A. Odhano; S. Gul and A.Q. Tareen (2009). Effects of sowing method and seed rate on growth and yield of wheat (Triticum aestivum L.). World J. of Agric. Sci., 5(2): 159-162. 
"تأثيرات نقص مياه الرى وطرق الزراعه على صفات النمو والاحتياجـات المائيه.

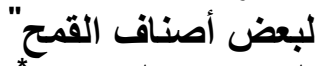

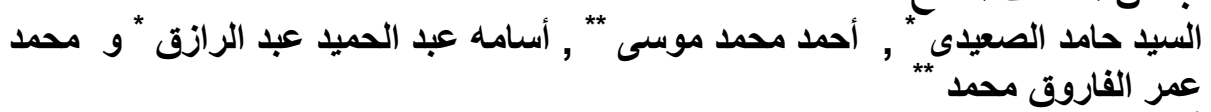

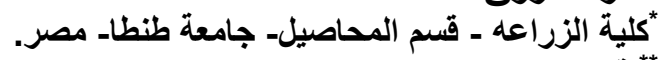
** قسم بحوث القمح - معهز بحوث المحاصيل الحقليه ـ مركز البحوث الزراعيهـ مصر.

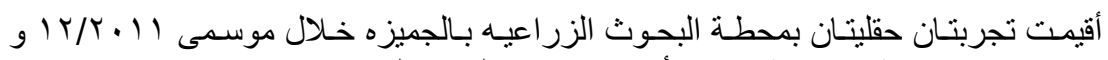

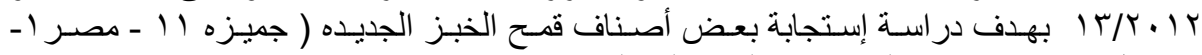

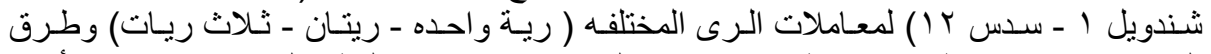
الزر اعه ( بدار - تسطير - مصاطب) وتم تنفيذ التجربـه فى تصميم القطع المنشقه مرنين فى أربع مكرات. وفيما يلى ملخص لاتهم النتائج المتحصل عليها:

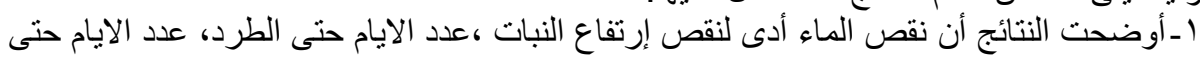

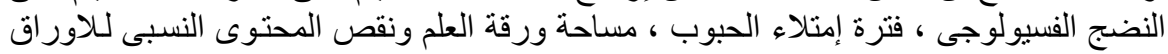

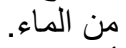
rـأثنارت النتائج إلى أن نقص الماء أدى الى زيادة كفاءة إستخدام مـاء الرى ومحتوى الكلوروفيل

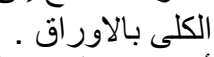

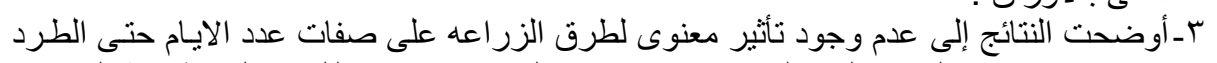

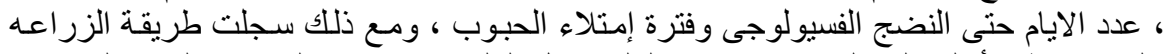

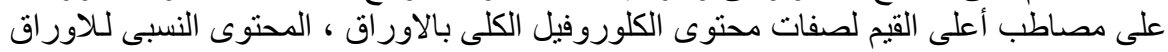

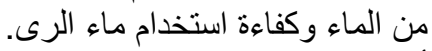

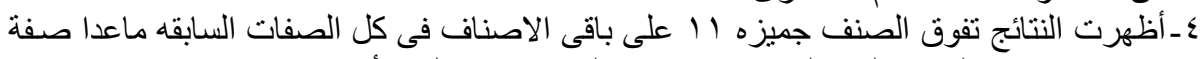

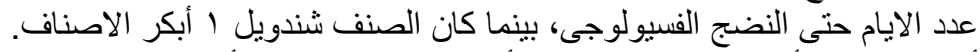

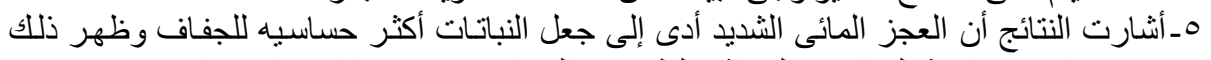

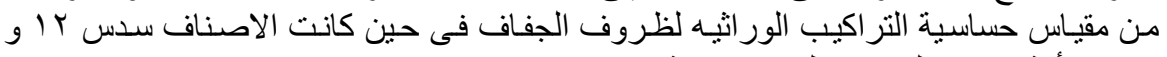

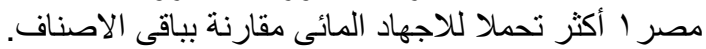

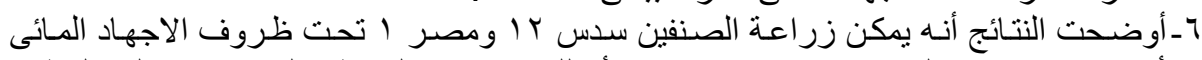

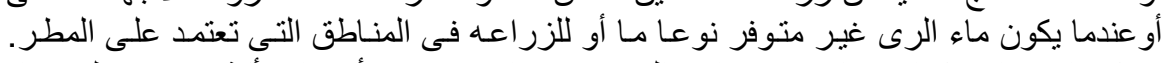

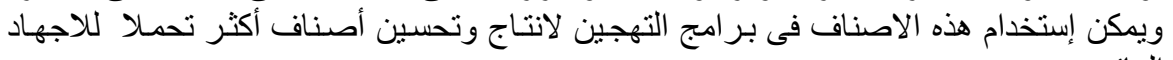

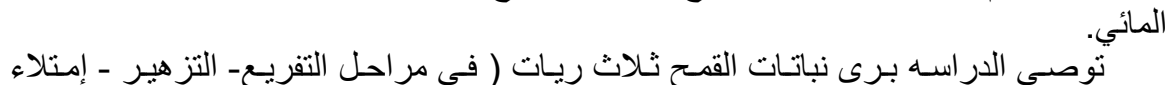

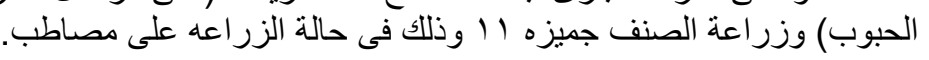


J. Plant Production, Mansoura Univ., Vol. 6 (5), May, 2015 
Table 4: Effects of irrigation numbers $(I)$, sowing methods $(M)$, cultivars $(V)$ and their interactions on plant height $(\mathrm{cm})$, days to heading (day), days to maturity (day), grain filling period (day), flag leaf area $(\mathrm{cm})^{2}$ and total chlorophyll content (SPAD value) in 2011/12 and 2012/13 seasons.

\begin{tabular}{|c|c|c|c|c|c|c|c|c|c|c|c|c|c|c|c|c|c|c|c|c|c|c|c|}
\hline \multirow[b]{2}{*}{ Variables } & \multicolumn{4}{|c|}{ Irrigation (I) } & \multicolumn{2}{|c|}{ LSD } & \multicolumn{4}{|c|}{ Sowing methods (M) } & \multicolumn{2}{|c|}{ LSD } & \multicolumn{5}{|c|}{ Cultivars (V) } & \multicolumn{2}{|c|}{ LSD } & \multicolumn{4}{|c|}{ Interactions } \\
\hline & $\mathbf{I}_{1}$ & $\mathrm{I}_{2}$ & $I_{3}$ & Sig. & 0.05 & 0.01 & $\begin{array}{l}\text { Broad- } \\
\text { casting }\end{array}$ & Drill & Beds & Sig. & 0.05 & 0.01 & Gem. & $\underset{1}{\text { Misr }}$ & $\begin{array}{c}\text { Shan. } \\
1\end{array}$ & $\begin{array}{c}\text { Sids } \\
12\end{array}$ & Sig. & 0.05 & 0.01 & $\begin{array}{l}1 \\
\times M\end{array}$ & $\begin{array}{c}1 \\
x v\end{array}$ & $\begin{array}{l}\mathrm{M} \\
\mathrm{x} \mathrm{V}\end{array}$ & \begin{tabular}{|l|}
$x$ \\
$M$ \\
$x y$
\end{tabular} \\
\hline \multicolumn{24}{|c|}{$2011 / 12$} \\
\hline Plant height & \begin{tabular}{|l|}
110.71 \\
\end{tabular} & 111.94 & \begin{tabular}{|l|}
113.50 \\
\end{tabular} & ** & - & 1.74 & \begin{tabular}{|l|}
110.61 \\
\end{tabular} & \begin{tabular}{|l|}
112.14 \\
\end{tabular} & 113.40 & ** & - & 0.84 & \begin{tabular}{|l|}
114.68 \\
\end{tabular} & 1110.61 & \begin{tabular}{|l|}
109.64 \\
\end{tabular} & \begin{tabular}{|l|}
113.27 \\
\end{tabular} & ** & - & 1.27 & NS & NS & NS & NS \\
\hline $\begin{array}{l}\text { Days to } \\
\text { heading }\end{array}$ & 103.65 & 105.10 & 106.21 & ** & - & 1.67 & 105.31 & 104.60 & 105.04 & NS & - & - & 103.47 & 105.58 & 106.75 & 104.14 & ** & - & 0.98 & NS & NS & NS & NS \\
\hline \begin{tabular}{|l|} 
Days to \\
maturity
\end{tabular} & 154.52 & 156.13 & 156.83 & ** & - & 1.63 & 156.23 & 155.73 & 155.52 & NS & - & - & 155.86 & 155.50 & 154.75 & 157.19 & ** & - & 1.14 & NS & NS & NS & NS \\
\hline $\begin{array}{l}\text { Grain filling } \\
\text { period }\end{array}$ & 49.91 & 50.88 & 51.73 & * & 1.17 & - & 50.92 & 51.13 & 50.48 & NS & - & - & 52.39 & 49.92 & 48.00 & 53.06 & ** & - & 1.56 & NS & NS & NS & NS \\
\hline Flag leaf area & 39.26 & 43.43 & 47.05 & $\star \star *$ & - & 1.97 & 41.10 & 43.26 & 45.38 & ** & - & 1.24 & 52.68 & 42.65 & 37.91 & 39.75 & $\star \star \star$ & - & 1.40 & NS & NS & NS & NS \\
\hline $\begin{array}{l}\text { Total } \\
\text { chlorophyll } \\
\text { content }\end{array}$ & 46.80 & 45.04 & 42.40 & ** & - & 1.74 & 44.72 & 43.13 & 46.38 & ** & - & 1.47 & 48.42 & 43.14 & 40.52 & 46.89 & ** & - & 1.43 & NS & NS & NS & NS \\
\hline \multicolumn{24}{|c|}{$2012 / 13$} \\
\hline Plant height & 113.12 & 114.53 & 115.77 & ** & - & 1.71 & \begin{tabular}{|l|}
114.57 \\
\end{tabular} & 113.26 & 115.59 & ** & - & 0.75 & \begin{tabular}{|l|}
117.91 \\
\end{tabular} & 111.04 & \begin{tabular}{|l|}
112.96 \\
\end{tabular} & \begin{tabular}{|l|}
115.98 \\
\end{tabular} & ** & - & 1.16 & NS & NS & NS & NS \\
\hline \begin{tabular}{|l|} 
Days to \\
heading
\end{tabular} & 101.04 & 103.21 & 104.38 & ** & - & 2.23 & 103.19 & 102.52 & 102.92 & NS & - & - & 100.58 & 101.53 & 105.50 & 103.89 & ** & - & 1.08 & NS & NS & NS & NS \\
\hline \begin{tabular}{|l|} 
Days to \\
maturity
\end{tabular} & 150.63 & 152.17 & 153.73 & ** & - & 1.60 & 152.65 & 151.79 & 152.65 & NS & - & - & 152.75 & 154.42 & 150.33 & 151.19 & ** & - & 0.95 & NS & NS & NS & NS \\
\hline $\begin{array}{l}\text { Grain filling } \\
\text { period }\end{array}$ & 48.96 & 49.35 & 49.58 & NS & - & - & 49.46 & 48.88 & 49.56 & NS & - & - & 52.17 & 52.89 & 44.83 & 47.31 & ** & - & 1.60 & NS & NS & NS & NS \\
\hline Flag leaf area & 43.30 & 46.95 & 49.17 & ** & - & 1.89 & 45.21 & 46.55 & 47.65 & ** & - & 1.07 & 52.54 & 41.19 & 43.33 & 48.82 & ** & - & 1.53 & NS & NS & NS & NS \\
\hline $\begin{array}{l}\text { Total } \\
\text { chlorophyll } \\
\text { content }\end{array}$ & 49.43 & 47.74 & 45.29 & ** & - & 1.71 & 46.20 & 48.82 & 47.44 & ** & - & 1.35 & 48.86 & 46.29 & 44.14 & 50.66 & ** & - & 1.45 & NS & NS & NS & NS \\
\hline
\end{tabular}

${ }^{\star},{ }^{\star \star}$ and $\mathrm{n} . \mathrm{s}$ indicate $\mathrm{P}<0.05, \mathrm{P}<0.01$ and not significant, respectively. 